\title{
Architecture in the process of social inclusion of homeless
}

\author{
Adam Rybka ${ }^{1, *}$, Anna Brudnicka ${ }^{1, * *}$ \\ ${ }^{1}$ Rzeszow University of Technology, Faculty of Civil and Environmental Engineering \\ and Architecture, al. Powstańców Warszawy 12, 35-959 Rzeszów, Poland
}

\begin{abstract}
The phenomenon of homelessness requires active support to stimulate the actions of socially excluded people in the process of leaving homelessness. The study exemplifies transfer of benefits from the design sector to the social service sector. Shelters or installations for homeless people give them, on the one hand, a chance to survive, on the other, signal of acceptance of their status. Is it necessary to design forms that consolidate their condition or initiate a process whose aim is to overcome the state of homelessness and social inclusion? The paper reveals how to engage homeless populations as clients participating in the design and building process. The study presents a project in the field of natural construction based on straw balls technology. Materials are common, cheap, local and biodegradable. Straw bale technology allows building intentional communities developing in direction of social, economic and environmental sustainability. The project tries to solve the main problems of homelessness through assurance of refuge, inclusion in society, motivation to work and to develop the ability of the homeless to cooperate. The target group can gradually achieve economic independence and become an active part of society.
\end{abstract}

\section{Introduction: homelessness and urban poverty in Poland}

\subsection{Homelessness sector in Poland}

In Poland homelessness is defined in the Act on Social Assistance. The definition says: "a homeless person is someone who does not live in living premises within the meaning of regulations on Tenants Rights and Municipal Housing Stock, and someone not registered for permanent residence within the understanding of regulations on General Registry and Identification Documents, as well as someone who does not live in living premises and is registered for permanent residence in premises where residence is not possible" [1]. Homessness can be defined on the basis of specific spheres, showing problems and deficits of homeless people. There are six major spheres of influence as a response to the social and professional challenges of (re) integration of homeless people: psychological, professional, health, living and housing, residential, social [2].

*Corresponding author: akbyr@prz.edu.pl, ${ }^{* *}$ a.brudnicka@prz.edu.pl 
Homelessness is a significant problem. The knowledge about this phenomenon is extremely important: about its scale and actions taken to combat homelessness. It is difficult to estimate the number of homeless in Poland. The database concerning this phenomenon has a large margin of error.

During the study of the number of homeless people, which was carried out on the night of the $8^{\text {th }}$ to the $9^{\text {th }}$ of February 2017, the communes diagnosed a total of 33408 homeless people, including 27911 men (83.5\%) and 5597 women (16.5\%) [4].

The vast majority of respondents were staying in specialized institutions $-24,194$ people (72\%), the remainder of persons were residing outside social establishments $-9,214$ people $(28 \%)$. The table below shows data from a survey about places where the homeless stay who didn't receive help [4].

Table 1. The number of homeless people diagnosed outside the specialized institutions (on the night of 8/9 February 2017) [4].

\begin{tabular}{|l|c|c|c|c|}
\hline \multirow{2}{*}{\multicolumn{1}{|c|}{ Institution }} & \multicolumn{4}{c|}{ Number of people } \\
\cline { 2 - 5 } & Total & Men & Women & Children \\
\hline abandoned places, gazebos & 4076 & 3237 & 746 & 93 \\
\hline $\begin{array}{l}\text { streets, staircase, bus/railway } \\
\text { station, trashes, basements }\end{array}$ & 2432 & 2154 & 278 & 0 \\
\hline other places & 2706 & 1998 & 481 & 227 \\
\hline Total & $\mathbf{9 2 1 4}$ & $\mathbf{7 3 8 9}$ & $\mathbf{1 5 0 5}$ & $\mathbf{3 2 0}$ \\
\hline
\end{tabular}

The experts indicate that the number of homeless people in Poland should be estimated at 60-70 thousand, but due to the complexity of the phenomenon it is also responsible to use a range of 30 to 300 thousand people (taking into account so - called gray zone e. g. people living with family from time to time and homeless only periodically) [5]. Counting the numbers homeless is made more difficult as a result of the absence of agreed definitions.

\subsection{Survival strategies based on recycling}

The data above indicates that $28 \%$ of homeless people live in informal settlements. Most definitions and measurements of urban poverty are based only on income-levels. The scale and depth of poverty of homeless people is not only an income problem. It is usually a struggle for survival. Homeless people create illegal camps in various parts of cities. The police support the city staff effort of getting rid of camps by taking out all the garbage that is left behind. The homeless moved out to build a new shelter. According to many residents of the camps, they together form a "community" which provides them more comfort and security than shelter and temporary housing programs.

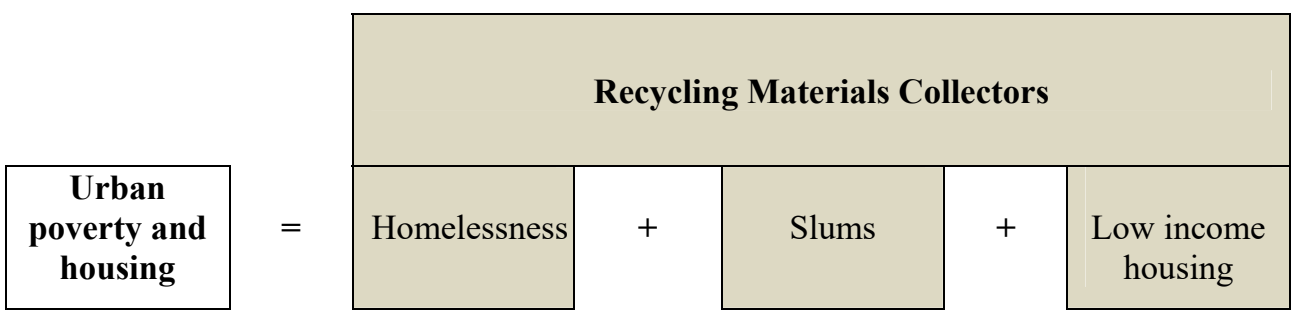

Fig. 1. Urban poverty, Housing and Recycling Material Collectors. 
The urban environment is becoming a vital niche to sustain the daily lives of the homeless. In the city various elements come together: the destiny of the population, people offering financial help, free food, services and institutions supporting the homeless, and an abundant availability of recyclable material. The ceaseless search for material survival strategies enabled the homeless to reuse discarded materials, assigning new meanings to them. These practices present many aspects and involve intense work. Collecting of products and materials, based on own criteria of adaptation and creativity, the homeless person reveals his search for autonomy [6].

Described behaviors confirm that the forms of support for homeless people should be based on social inclusion and help in determining a permanent place to live. The perception and experiences of homeless people in relation to the public spaces they occupy and identify as their own, remains an under-explored area of socio-cultural research.

\section{Inclusion by design}

The purpose of this thesis is an attempt to determine how architects can help to solve major homelessness problems by invitation to participate in the design process. Presented forms of shelters, building technologies and materials refer not only to nightly shelter. It has also a special importance in their social inclusion [18].

Participation in making decisions about the design, planning, building and management of places can enhance a sense of belonging. It can increase feelings of security and remove barriers between communities. Design practices could make a relevant contribution to build an investment for homeless people, on their own [8].

\subsection{Knowledge spillovers}

The mechanisms by which the design intervention leads to innovation in the social sector, exemplifies those processes where social services for homeless people benefit from the application of design and participatory led activities. The presented method of work aims to engage diverse stakeholders [9] (social workers, designers, psychologists, local authorities and above all homeless people) to responsibly participate in designing and building housing infrastructure. From the practical point of view, the homeless people build their own home. Their self - esteem, mood and personal creativity will be enhanced. The homeless people can start to gain a sense of belonging to a group.

The way the idea is working is based on a collaborative environment. This approach allows the combination of the theoretical dimension of the research and the practical outcomes of the project. The initiative benefits all participants: creating new forms of assistance for homeless (social sector), and developing research on low-emission construction technologies (building sector).

\subsection{Financial and ecological aspects. Cost - effective building technologies}

The challenge was to find cost - effective and above all functional solution to the housing problem. The article analyzes the issues of modular architecture, adaptive reuse, recycled pallets, shipping container architecture and natural building techniques.

Modular architecture often utilizes pre - made materials like shipping containers and wooden pallets. This technology allows one to build homes cheaply and quickly [19].

Adaptive reuse is the process of changing a building's function to accommodate the changing needs of its users. Old buildings can be economical through lower demand for building materials [20]. 
Taking into account financial possibilities of the target group and their survival strategies based on collecting discarded materials, the proposed solution is based on assumptions of natural building lean on constructions using minimally processed, natural, recyclable and locally available materials. Low-tech architecture is made by their owners with local materials with local skills and techniques, as energy-efficient and self-sufficient. Materials are common, cheap and biodegradable.

The project has an educational features, hence the decision to introduce solutions guided by the principles of sustainable development. The eco-efficient solutions are improvements in conventional design, but still have a negative impact on the environment. Regenerative design is a part of sustainable development, but it is not the same as sustainable design. Sustainability is a process that endures without degradation, but it does not regenerate itself. It is like a plastic bottle - sustains; a plant - regenerates. Sustainable design has to task to provide elementary human needs without environmental degradation. Regenerative design goes further [10].

As design moves from conventional, to green, through sustainable and onto restorative and regenerative, less energy is needed. Regenerative development for the built environment could become a conduit for producing resources and energy, remedying past pollution and transforming and filtering waste into health -giving resources. Another key benefit is understanding local traditions and indigenous knowledge, which can preserve or create cultural identity [11].

\section{Homeless to home: eco - community}

\subsection{Targets of project}

One of the systems for solving the homelessness problem is the housing led model, supported and promoted by the European Commission and European organizations dealing with homelessness, including FEANTSA (European Federation of National Organizations Working with Homeless People). This approach proposes a departure from institutional support in facilities, e.g. night shelters, for support in the environment, e.g. in housing [8].

This paper presents a conceptual project of eco - village for homeless. This Case study makes an example as to how the homeless problem can be overcome.

The purpose of the project was to verify whether small a group housing within a central unit is able to create an intentional community developing in the direction of social, economic and environmental sustainability focused on the principles of sustainable development [12]. The proposed complex is intended to show advantages of natural building. The project's working method is engaging of the homeless people in the creative workshops as a part of social inclusion.

\subsection{Idea}

An important aspect was to define the features of the social structure of the target group. Their real needs and limitations were taken into account. It was very important to include aspects such as economy, durability, sustainability, saving time and materials, and productivity. Following this process, engineering facilities were designed based on the technology of straw bale being a variation of natural building, which is based on the principle of sustainability.

The basis for implementing described solutions is cooperation with social welfare bodies and government programs for financing social housing for the homeless. Involvement of homeless people in building their own shelters could minimize the costs associated with obtaining construction materials and realization of project. 
An example of an implemented idea is a house for the homeless in Pabianice. On the initiative of the Association of Abstainers "Granica" in 2008 began construction of a house for the homeless. The building of the house involved homeless people who were in a hopeless life situation, without a home, perspectives for the future, ambitions, job skills. These people participated in the process of building their own shelter. For the homeless, the creation of a home gave them a sense of security. The materials were donated by private entrepreneurs, sponsors, and people of good will. The involvement of the mentees in the construction was a form of therapy through work [17].

This project goes further. The proposed technology allows the reduction of the costs of building materials. For the construction sector, it is a chance to conduct further researches and to promote the technology of straw bales.

Following this process, a project was obtained that proposed the greatest possible economic benefits of construction and use of natural resources, follows the goal of creating shelter for homeless people and that, in addition, proposes new forms of integration and collaboration with the closest society.
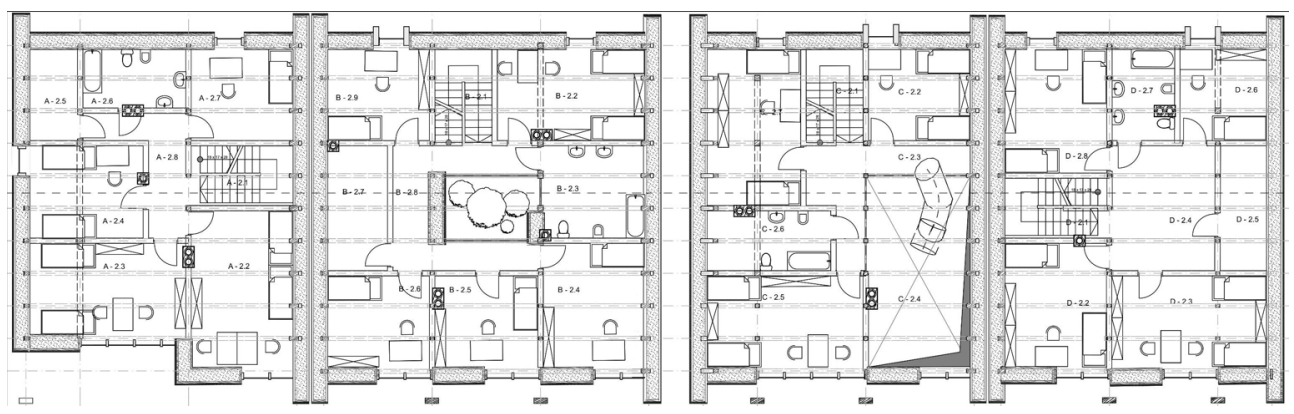

Fig. 2. An example of the functional arrangement (archive of Anna Brudnicka).
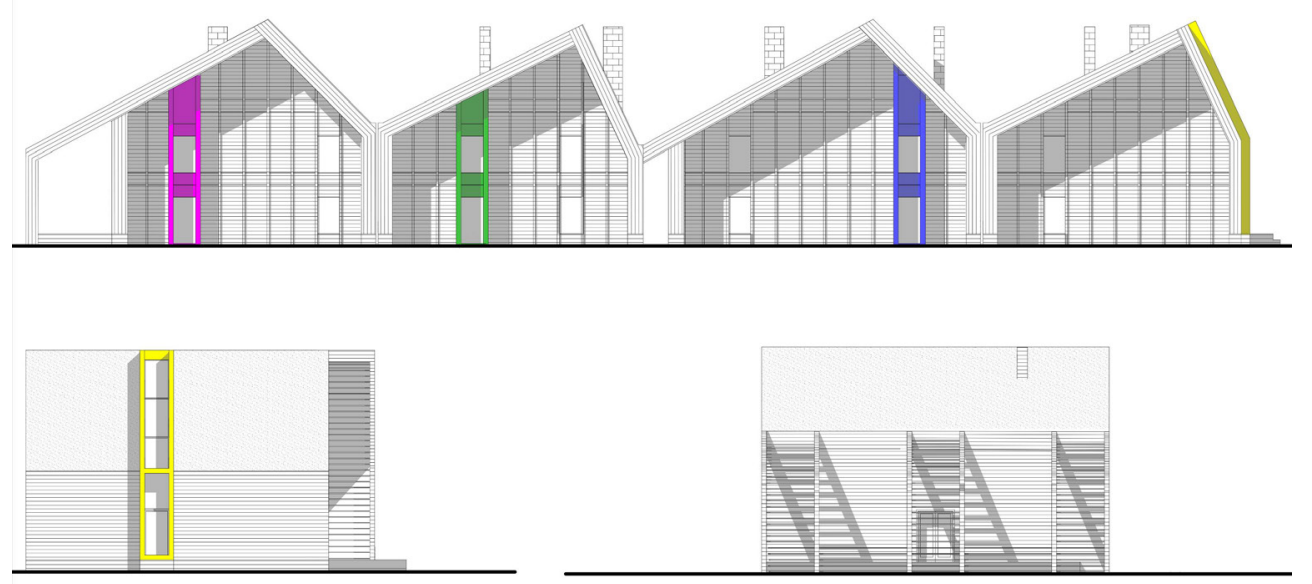

Fig. 3. Elevations (archive of Anna Brudnicka). 


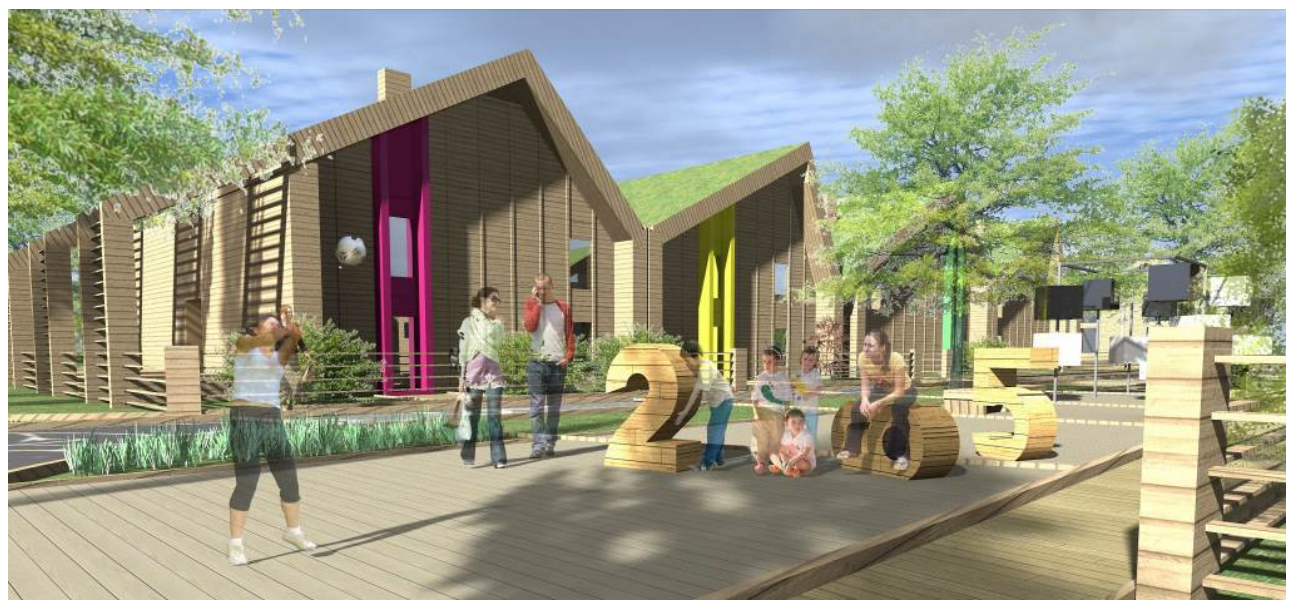

Fig. 4. Passage between segments (archive of Anna Brudnicka).

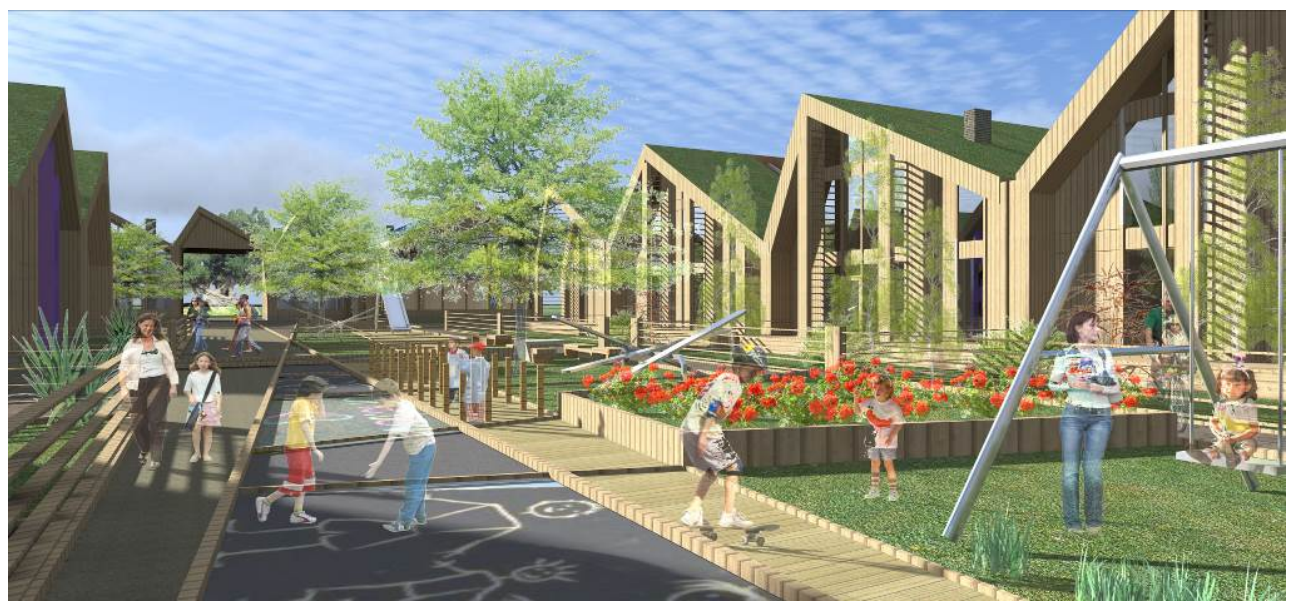

Fig. 5. Passage between segments, another view (archive of Anna Brudnicka).

Architecture of objects is restrained and friendly. In modern way connects the traditional elements of the urban layout with natural, simple finishes. Passages between the houses play a role of focus that physically connect a group of houses. To prevent the phenomenon of limitation, segments are not absolutely tight in their ranks.

\subsection{Technical solutions}

Straw - bale construction is a building method that uses bales of straw as structural elements, building insulation, or both. The main advantages of the system included: use of renewable materials, low costs, easy availability, fire - retardant and high insulation value. The applied technology allows one to reduce the construction costs of building a fully functional home, while also meeting functional and aesthetic expectations of modern society $[15,16]$. 


\subsection{Materials}

The cereal plants have a natural ability to regenerate. It is annually renewed and widely available, which eliminates the necessity of transport. The construction of a straw house is characterized by a zero or even a minus carbon footprint [14], [15]. It is supported by low energy expenditure during straw dicing and the absorption of carbon dioxide during plant growth. The PEI embedded energy content is characterized by the amount of nonrenewable energy needed to process the product. In the case of straw cubes, the following production processes are taken into account: pressing of cubes, production of string, energy required for loading and transport [13]. Unpolluted straw obtained from demolition of an object in straw bale technology can be incorporated back into the natural course of matter, e.g. as a compost.

An important advantage of the partition made of straw finished with clay plaster is very good thermal insulation. Houses made of straw cubes obtain standards of passive buildings. Straw as a construction raw material meets a number of requirements for environmentally friendly materials and contributes to the maintenance of the principles of sustainable development.

Thermal transmittance (U-value) of the wall made with straw bale depends on the wall thickness and stalk positioning (fig.9). The orientation of the stems has the following effect on the thermal insulation of the partition [14]:

- along the stems: $\lambda=0,080[\mathrm{~W} / \mathrm{m} \cdot \mathrm{K}]$

- across the stems: $\lambda=0,052[\mathrm{~W} / \mathrm{m} \cdot \mathrm{K}]$

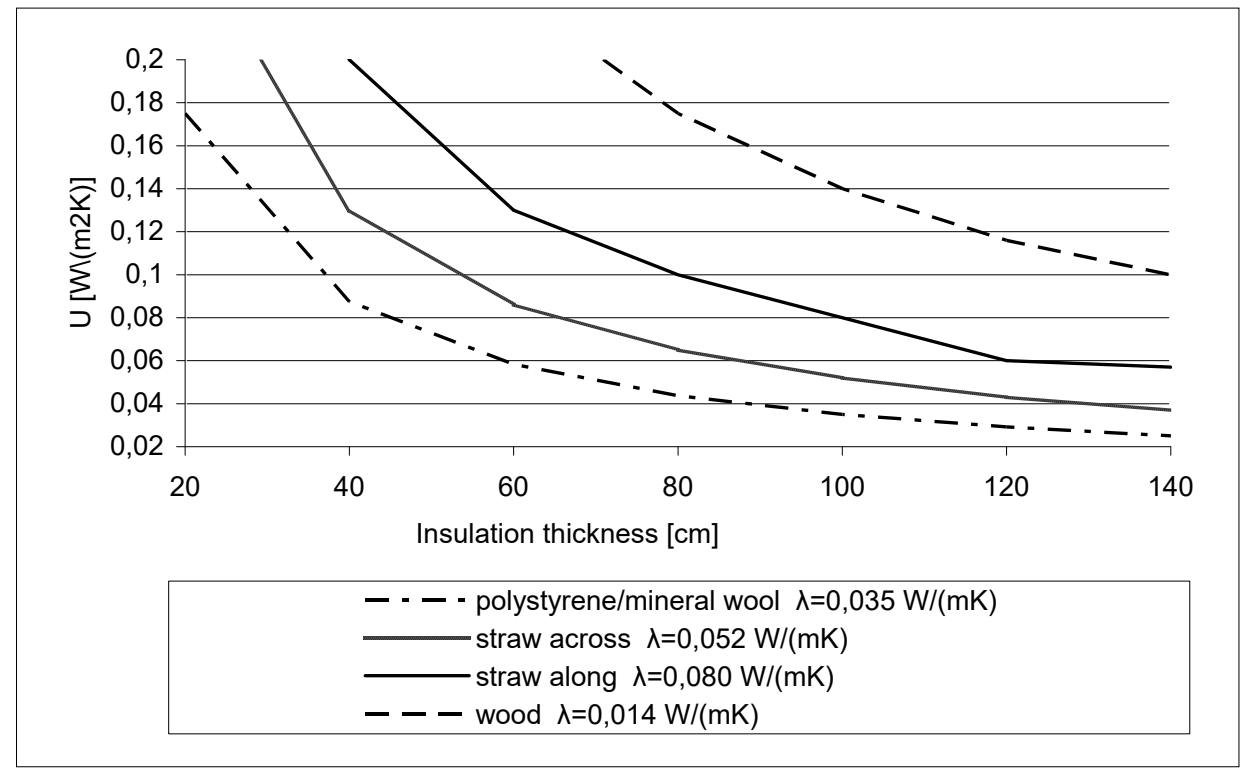

Fig. 6. Thermal transmittance depending on the thickness of the straw layer and the arrangement of the stems. Own elaboration based on German technical approval 23.II-1595 (2014). 


\section{Conclusions}

The paper seeks to analyze the phenomenon of social and environmental disaster and its connection with design in urban areas. The architecture of street homelessness reveals that public consciousness didn't offer permanent solutions to the problems of homeless people. Presented work shows that local governments need to look at their actions from a completely different perspective. The study of the changes in the social structure shows that ideas relying on experimental programs, education, training, volunteering are the only way out of homelessness.

The project tries to answer the question concerning how a homeless problem can be overcome by knowledge spillovers from the architectural design sector. The main challenge was to combine low costs sustainable building and a fulfilling lifestyle to create an optimal environment for the community. Looking for an answer to the question 'how to reduce the consumption of mass goods without decreasing quality of life?' presents the advantages of low-tech architecture which is made by their owners with local materials with local skills and techniques, as energy-efficiently and self-sufficiently as possible.

This project illustrates reflection on ecology and its relationship to architecture. The main purpose was to contribute to getting a better and fuller understanding of architecture in the context of its impact on the environmental sustainability, prices, and access to a broad audience. The project is an attempt to show the general trend of the possible development and popularization of ecological architecture in the city.

The advantages of straw bale construction have been recognized in many countries and are becoming more and more popular. In Poland, it is still an experimental construction. The barrier is the lack of legal regulations concerning construction technologies using straw cubes and social awareness questioning the principles of construction and operation of the described facilities. Described knowledge spillovers from the design sector to the social sector can work in the opposite direction. Implementation of facilities in the presented technology would contribute to development of this field of science. Changes in legal conditions would undoubtedly contribute to the spread of this branch of construction and would increase the degree of recognition of this phenomenon.

\section{References}

1. Ustawa o pomocy społecznej (Act on Social Assistance of 12-March 2004)

2. A. Dębska-Cenian, P. Olech, (Od ulicy do samodzielności życiowej. Standardy społecznej izawodowej (re)integracji $w$ sześciu sferach, Drukarnia Wydawnictw Naukowych sp. z o.o, Gdańsk 2007)

3. Protokół posiedzenia Komisji Standaryzacji Nazw Geograficznych poza Granicami Rzeczypospolitej Polskiej, Warszawa (2015)

4. Ministerstwo Rodziny, Pracy i Polityki Społecznej. Departament Pomocy i Integracji Społecznej, Sprawozdanie z realizacji działań na rzecz ludzi bezdomnych w województwach $w$ roku 2016 oraz wyniki Ogólnopolskiego badania liczny osób bezdomnych (8/9 luty 2017), Warszawa (2017)

5. P. Olech, Charakterystyka sytuacji Polski w kontekście badania problematyki bezdomności, Materiał przygotowany na potrzeby realizacji projektu MPHASIS, access: http://docplayer.pl/4268629-Aneks-nr-3-projekt-krajowy-program-rozwiazywania problemu-bezdomnosci-i-wykluczenia-mieszkaniowego-2014-2020-projekt-wersja-nr-10-z31-12.html (access 2018.05.24) 
6. M.C.L. Santos, Moving beyond homelessness: how design can be an instrument for change, In: International Association of Societies of Design Research Conference, Hong Kong Polytechnic University (2007)

7. A. Pospieszyl http://radio.opole.pl/100,176699,obozowisko-bezdomnych-w-parku-miejskimmieszkanc (access 18.01.2018)

8. Centrum Rozwoju Zasobów Ludzkich, Projekt systemowy „Tworzenie i rozwijanie standardów ustug pomocy i integracji społecznej" $w$ zadaniu $n r 4 \quad w$ zakresie standaryzacji pracy z bezdomnymi w tym: opracowanie Modelu „Gminny Standard Wychodzenia z Bezdomności” (Gdańsk 2014)

9. Ł. Bajda, A. Rybka, JCEEA, 34, 7-18 (2017)

10. B.Reed, Shifting our Mental Model - "Sustaina bility" to Regeneration. A paper submitted for the Conference: Rethinking Sustainable Construction 2006: Next Generation Green Buildings, September 19-21 (2006)

11. M. Pedersen Zari, Regenerative design for the future, Build 115 (December 2009/ January 2010)

12. M. Szpytma, A. Rybka, JCEEA, 33, 321-328 (2016)

13. B. Krick, Untersuchung von Strohballen und Strohballenkonstruktionen hinsichtlich ihrer Anwendung für ein energiesparendes Bauen unter besonderer Berücksichtigung derlasttragenden Bauweise, Dissertation, Fachbereich Architektur Stadt-und Landschaftsplanung, Universitat Kassel, Kassel university press (2008)

14. G. Minke, B. Krick, Podręcznik budowania z kostek stomy, Fundacja Cohabitat, Łódź (2015)

15. F. D’ Allessandro, F. Bianchi, G. Baldinelli, A. Rotili, S. Schiavoni, Journal of Building Engineering 11, 56-68 (2017)

16. A. Evrard, B. Biot, G. Keutgen, F. Lebeau, L. Courard, A. De Herde, (Straw-bale walls for sustainable architecture: Improving and promoting straw-bale use in European Buildings, PLEA 2015 - Architecture in (R)Evolution (Bologne, du 09/09/2015 au 11/09/2015). In: M. Cucinella, G. Pentella, PLEA2015 - Architecture in (R)Evolution, Ass. Building Green Futures: Bologna (2015)

17. Opis dobrej praktyki, In: http://www.prezydent.pl/download/gfx/prezydent/pl/ witrynaobywatelska/3170/projekty/286/opis.pdf (access 26.05.2018)

18. S. Davis, The Journal of Sociology \& Social Welfare, 32, (2005)

19. https://inhabitat.com/prefab-friday-the-manifesto-house-in-chile/ (access 27.05.2018)

20. K. Rathmann - Sustainable Architecture Module: Recycling and Reuse of Building Materials, (National Pollution Prevention Center for Higher Education 2001) 